\title{
Improving Students' Learning Outcomes by Implementing Simple E-Voting Application
}

\author{
Muhammad Arsyad \\ SDN Pelambuan 7 Banjarmasin \\ Bina Karya Banjarmasin, Indonesia
}

\author{
Siti Aulia \\ STKIP PGRI Banjarmasin \\ Banjarmasin, Indonesia \\ st.aulia7@gmail.com
}

\begin{abstract}
From the observations in SDN Pelambuan 7 Banjarmasin, the learning outcome on local election learning material was still low. This is due to several factors, including the students' ability to make sense of the patterns and the use of less appropriate learning strategies so the learning does not run maximally and optimally. It is, therefore, important to be improve the learning outcome of the students through classroom action research (CAR) by implementing e-voting application in local election learning material to improve students' learning outcomes. This research was conducted in two cycles in which each cycle consisted of two meetings. The subjects were 29 students of class VI at SDN Pelambuan 7 Banjarmasin, consisting of 15 male and 14 female students. Sources of the data were obtained from the teachers and students in the form of quantitative and qualitative data. The data were obtained through observation which were recorded on a data sheet for observation and the students' learning outcomes were obtained through written tests including the evaluation of the students' work and the final evaluation and formative test. The results showed that the activities of teachers and students by using the simple e-voting application on local election learning material increased students' learning outcomes. In conclusion, it is recommended for teachers to apply a simple e-voting application in order to gradually and continuously assess patterns and appropriate learning strategies to improve the process and outcomes of learning.
\end{abstract}

Keywords-Learning Outcomes, Local Election Learning, EVoting Application

\section{INTRODUCTION}

\section{A. Background of the research}

The Preamble of the Constitution of the Republic of Indonesia Year 1945 has given a mandate to us that the national goal is to protect the entire Indonesian nation and the entire homeland of Indonesia and to promote the general welfare, educate the nation and participate in implementing world order based on freedom, lasting peace and social justice. To achieve the national goals, education is a contributing factor and decisive in the process of goal realization.

Developing or underdeveloped countries are five years behind in terms of development and pure science research as a key in the delivery of high-level technology [1]. The development of science in the developing or underdeveloped countries is more directed to pragmatic sciences useful for society in the short and medium term. "The West" has invested a very large budget to conduct in-depth research on the pure sciences because that is where the innovation by innovation in the field of education and technology occurs dynamically in creative and accelerated manner.

This opaque reality is experienced by the world of education in this country which always adopts the western discourse. The question is "when is this nation able to become a manufacturer of world-class education that can be taken into account by other countries? This is the question we must think of together to improve the quality of education in this country.

Good quality education will lead a nation toward a revival [2]. Indonesian children are only able to control $30 \%$ of the reading material and it is difficult for them to answer the questions in the form descriptions that require reasoning. Perhaps it is because the reading material is often memorized (not experienced) as the results of multiple choice questions that are very commonly used in Indonesia.

Curriculum Education Unit has a goal set out in the all subjects, one of which is Civic Education. The aim of this subject is to enable learners have the ability to: (1) know the concepts related to people's lives and the environment (2) have the basic ability to think logically and critically and have the curiosity, the inquiry, problem solving and skills in the life of citizenship, (3) to have the commitment and awareness of the values of citizenship and humanity, (4) the ability to communicate, collaborate and compete in a pluralistic society, locally, nationally and globally [2].

To learn the concepts contained in Civic Education, critical thinking and rightful reasoning is necessary. Inside the concepts, Civic Education is learning concepts that seem simple but sometimes make students become confused. So that learners' achievements in Civic Education do not correspond to the learning objectives to be achieved. Which is the achievement of students who exceed the score of the minimum completeness criteria in SDN Pelambuan 7 Banjarmasin.

Improving the quality of learning will require refinement of learning in accordance with the purpose and nature of Civic Education. Students should be encouraged to interact with their peers in education, and given the responsibility of finding and obtaining their own education, so that students feel a healthy competition and can increase the motivation in the learning process.

Many factors cause students' learning outcomes and learning achievement of Civic Education at SDN Pelambuan 7 
Banjarmasin irrelevant with the expected goals. One of the factors is that learners do not have the ability to use reasoning in the patterns and behaviour as well as the ability to make generalizations, compile evidence or explain ideas and statements in Civic Education.

In addition, factors that greatly affect the difficulty in understanding the learning of Civic Education in SDN Pelambuan 7 Banjarmasin are the less precise methods and approaches used by the teacher in the learning process which make the students do not understand the material. Moreover, some of the weaknesses that occur in the process of learning, especially applied by teachers at SDN Pelambuan 7 Banjarmasin in subjects at the sixth grade Civic Education, are as follows. There is still a paradigm that education can be transferred to the students right away. Using such assumptions, teachers focus Civic Education on the effort of pouring education as much as possible to students. In general, teachers at SDN Pelambuan 7 Banjarmasin still are applying lectures, so students' skills in practicing the concepts they learn are very low. Thus, learning is perceived as unhelpful, uninteresting and boring.

Similarly happened in SDN Pelambuan 7 Banjarmasin, based on the researchers' observations, the students' learning outcomes of Civic Education were low. Based on the observation on October 10 2013, the results of learning achieved by sixth graders in Civic Education were 29 as the lowest score with a very low category and were 64 as the highest score with medium category. The average score was 51.80 and the students' learning outcomes of Civic Education were still low.

The learning outcomes of the students on Civic Education in SDN Pelambuan 7 Banjarmasin, especially in the sixth grade were considered as low based on the SKM (Minimum Passing Standard) at SDN Pelambuan 7 Banjarmasin specifying the SKM for Civic Education subject for sixth grade is 65 . In fact, the students' learning outcomes on Civic Education were still far below the SKM. There are allegations that the poor performance of students is influenced by the approach and learning media used. Based on the aforementioned findings, one of the innovations that can be applied to deal with is the implementation of simple e-voting application. The learning medium is expected to increase the motivation of students due to the interaction among the students themselves both physically and psychologically. These interactions can occur among students which ultimately improve student learning outcomes.

Based on the aforementioned description of the problems, the researchers intended to give concrete alternative solution to overcome these problems. The alternative is implementing learning activity of this material using a simple instructional medium of e-voting applications. By using this application which was designed effectively, positive interactions can occur from any direction and it is based on PAIKEM, an Indonesian acronym (Active, Innovative, Creative, Effective and Fun).

Therefore, the researchers considered that it was necessary to do the study entitled "Implementing Simple E-Voting Application to Improve Students' Learning Outcomes".

\section{B. Formulation of the Problem}

Referring to the background, the researchers can draw formulation of the problem as follows:

1. How does the activity of Teacher in Implementing Simple E-Voting Application To Improve Students' Learning Outcomes At SDN Pelambuan 7 Banjarmasin?

2. How does the activity of students in Implementing Simple E-Voting Application To Improve Students' Learning Outcomes At SDN Pelambuan 7 Banjarmasin?

3. Does an increase happen in Implementing Simple EVoting Application To Improve Students' Learning Outcomes At SDN Pelambuan 7 Banjarmasin?

\section{Problem Solving Plans}

Based on the description above, SDN Pelambuan 7 Banjarmasin confronted by the problems of learning is the use of conventional methods and models, less attractive learning and students tend to be passive so that the student learning outcomes is low. If the problem is allowed to continue and not repaired, the result of learning objectives and targets cannot be fully achieved, so that student achievement will also be decreased.

According to the researchers, the use of teaching models and the right teaching media is an alternative in an effort to foster a sense of fun for students to attend classes so that students can learn Civic Education integrated with a sense of fun so as to awaken the giant within (the brain) which still asleep to absorb the information given by teachers and learning environments. The teaching strategy using media, simple evoting applications, were applied by teachers are not expected to take place more effectively and efficiently.

\section{METHOD}

\section{A. Description of Research Setting}

This Class Action Research was conducted at SDN Pelambuan 7 Banjarmasin, Jalan Bina Karya Simpang Jagung Rt. 61 No. 5 Kelurahan Pelambuan, West Banjarmasin District, Kota Banjarmasin. The research was conducted at the sixth grade with the number of 20 students, consisting of 10 male and 10 female. The classroom of VI grade at SDN Pelambuan 7 Banjarmasin has dimension of $7.5 \mathrm{~m} \mathrm{x} 7.5 \mathrm{~m}$ with 20 students' desk.

The learning activities in the academic year 2014/2015 in the sixth grade of Elementary School Pelambuan 7 Banjarmasin still use KTSP, for the 2013 Curriculum has not been implemented in this school because the curriculum book has not been distributed to support teaching and learning. Similarly, standard and basic competencies are applied in accordance to KTSP with a number of lessons for the subjects of Civic Education Education of 2 lesson hours per week with an allocation of $2 \times 35$ minutes.

The researchers also conducted interviews with sixth grade teacher. The interviews were conducted with teachers to identify early problems in learning, discussing the difficulties of teachers in implementing the learning of Civic Education, 
Civic Education learning outcomes and the activities of the students in the learning process. The teacher stated the appropriate learning model is hard to apply if the learning materials are abundant while the time available that listed in the syllabus is very little. Therefore, teachers focus Civic Education on the effort of pouring as much knowledge as possible to students. In general, teachers at SDN Pelambuan 7 Banjarmasin still apply lecturing technique, so students' skills in practicing the concepts they learn are low, making the learning perceived as unhelpful, uninteresting and boring.

The joint research of Civic Education subject teachers of sixth grade formulated and used methods and models whose goal was the achievement of learning outcome and increase the activity of the students in the sixth grade on Civic Education subject. Based on the low score on students' learning outcomes of Civic Education in SDN Pelambuan 7 Banjarmasin, the researchers were interested in doing research using simple evoting application.

\section{B. Research Preparation}

The observer in this study was a teacher at SDN Pelambuan 7 Banjarmasin, who served as Civic Education teacher of Class VI and has additional duties as Principal in SDN Pelambuan 7 Banjarmasin. The reason for choosing the teacher as the observer because she has had sufficient experience in conducting various studies with a fair and even very good mark.

\section{Class Action Implementation}

The steps of conducting the research were as follows:

1. Designing learning scenarios by using the approach of learning media to produce simple e-voting application

2. Preparing a means of learning and media that support learning which helps the implementation of the problem solving

3. Making the observation sheet to see how the learning conditions in the classroom is when the simple e-voting application is used and implemented

4. Making the observation sheet to see the activities of students and teachers when conducting activities and learning in the classroom

5. Designing an evaluation tool for Civic Education subject to see their learning ability and the results before and after use of simple e-voting application

\section{RESULTS AND DISCUSSION}

Based on observations and analysis of the data, an increase in activity and learning outcomes of Civic Education in the subject of election freedom in Indonesia was found. The increase was found on the activity of the teacher, student activity, learning outcomes and student mastery level.

\section{1) Teacher's Activities}

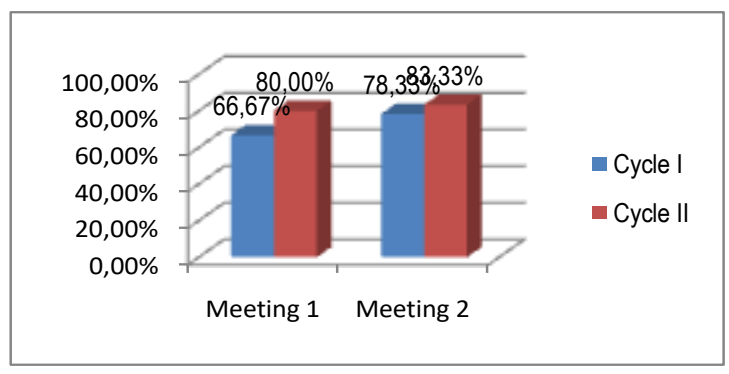

Fig. 1. Increase of Teacher's Activities

Based on the Fig. 1, it can be seen that the activities of teachers in the implementation of simple e-voting application were quite effective, but still not optimal. Seen in the first meeting, the activities of teacher obtained percentage value of $66.67 \%$ with a fairly good result. On the second meeting, teacher's activity increased earning $78.33 \%$ with a good level. All the planned activities were very well done. On the second cycle of learning activities, the activities of teacher were also stated quite effective and very optimum. Seen in the first meeting, activities for teacher obtained the average score of $80 \%$ with very good level. Furthermore, at the second meeting, teacher's activities increased and obtained the average score of $83.33 \%$ with a very good level. All the planned activities can be carried out well. This results show that there is an increase in the learning process by the teacher.

\section{2) Students'Activity}

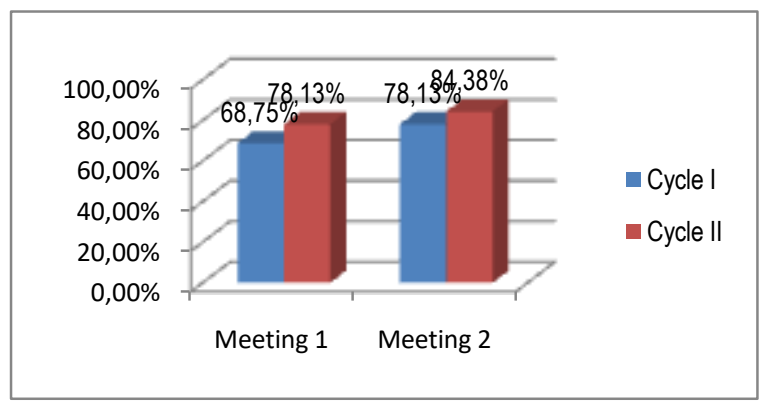

Fig. 2. Increase of Students' Activities

Based on the chart in Fig. 2, the activities of students in learning by using simple e-voting application in the first cycle increased. It can be seen in the observation sheet of students' activity on the first meeting which showed the score of $68.75 \%$ with a fairly good level. At the second meeting, students' activities increased to reach value of $78.13 \%$ with a good level. All activities planned were carried out well. Moreover, on the second cycle, students in learning activities using simple evoting application showed an increase in their activities. It can be seen in the observation sheet of students' activities at the first meeting of the second cycle which showed the score of $78.13 \%$ with a good level. At the second meeting, students' activities also increased to the average score of $84.38 \%$ with a very well level. All the planned activities can be carried out well. This fact showed an increase in the learning process by students. 


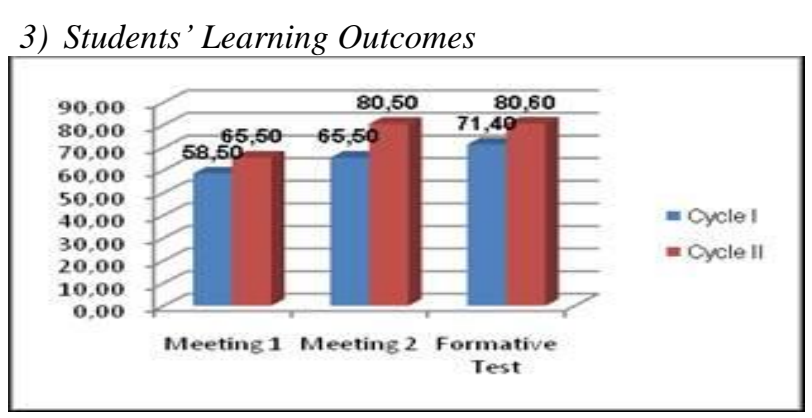

Fig. 3. Increase of Students' Learning Outcomes

Based on Fig. 3, the average value of students' learning outcomes at the first meeting of the first cycle was 58.50 with the percentage of $40 \%$ indicating students who passed the standard and 60\% indicating students who did not pass. At the second meeting, the average value was 65.50 with the percentage of 55\% indicating students who passed the standard and $45 \%$ indicating students who did not pass. Moreover, the results of formative test at the first cycle showed the average value of 71.40 with $65 \%$ of mastery level, and $35 \%$ of students did not pass the standard. Based on the average value of each meeting, there was an evident significant improvement, but not yet reached the level of completeness/standard in classical way as the percentage of completeness is still below the passing standard.

On the second cycle, students' learning outcomes at the first meeting obtained the average value of 65.50 with the percentage of passing standard achevement of $35 \%$, and $65 \%$ of students did not pass. At the second meeting, the average value was 80.50 with $75 \%$ of mastery level, while $25 \%$ of students did not pass. The results of the formative test at the second cycle (formative II) revealed the average value is 80.60 with 95\% mastery level of students who passed the standard, while only $5 \%$ of students did not pass. Judging from the average value of each meeting, there is a very significant increase and has reached a level of mastery in classical way as seen from the percentage of achievement compared to the minimum passing standard.

\section{4) The Percentage of Students' Mastery Learning}

Learning outcomes and students' learning mastery level still cannot reach the target and the minimum passing standard which has been established, so the implementation of the classroom action research continued to the second cycle. However, after considering the results of learning and mastery learning level of students in the second cycle, the minimum passing standard has been achieved by the students, so the implementation of the research was successful and has achieved the set targets. The detailed of students' mastery learning can be seen in Fig. 4.

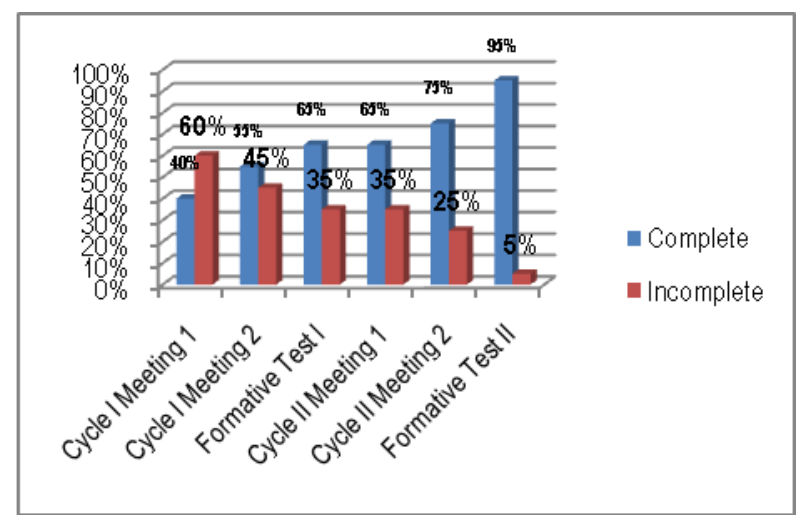

Fig. 4. Increase of The Percentage of Students' Mastery Learning

\section{B. Discussion}

Implementation of learning by teachers is constantly increasing. This is proven by the increase in the percentage of teacher' quality activities, namely $66.65 \%$ at the first meeting of the first cycle, $79.99 \%$ at the second meeting of the first cycle, $79.99 \%$ at the first meeting of the second cycle and $89.99 \%$ at the second meeting of the second cycle. In cooperative learning, teachers will tend to be successful if [3]:

a. the teacher stresses the importance of collective efforts in addition to individual efforts in learning;

b. the teacher requires all students (not only students who are smart) to obtain success in learning;

c. teachers want to instill, that students can learn from other friends and learn from the help of others;

d. the teacher wants to develop the communication skills of students as part of the curriculum;

e. the teacher wants the students to improve motivation and increase their level of participation;

f. the teacher requires the development of students' ability to solve problems and find different kinds of problem solving;

It is also in line with the opinion of [4] that cooperative learning can bring about the requirement for students to learn to think, solve problems, and integrate knowledge with skills. Cooperative learning is a form of learning that can improve the learning system that so far has lacked.

Activities of students in learning by using simple e-voting application are fairly supporting and active. This is seen on the observation sheet of students' activity which showed that all the planned activities can be carried out as well with the increasing percentage. Learning activities of students have also increased. This is evidenced by the percentage of completeness of students from the first cycle to the second. It is also proportional to the percentage of students' mastery learning.

Through cooperative learning, some perspectives, such as motivation, social perspective, the perspective of cognitive development and cognitive elaboration perspective can be explained. Motivation perspective means that the award given to the group allows each member of the group be willing to help each other. Thus, the success of every individual is 
essential for the group's success. This matter will encourage each member of the group to fight for the group's success.

This is according to the experts who stated that the role of teaching and learning activities both intrinsic and extrinsic motivation is needed. With the motivation, the students can develop activities and initiatives, direct and maintain diligence in learning activities [5].

The level of learning completeness at each meeting also increases in terms of learning outcomes. Based on the findings, the individual mastery of learning at the second cycle has increased compared to learning completeness individual at the first cycle. This increase is due to implementation of cooperative model strategies on the subjects of civic education in the sixth grade SDN Pelambuan 7 by using e-voting application. This is consistent with expert opinion that through cooperative learning strategies, learners are more accountable for learning, develop students' skills, improve learning outcomes and develop the ability to solve all the problems carefully and precisely. Accordingly, the simple e-voting application designed and used by the researchers is very relevant to learning process and learning results.

We need to realize that students are the main subjects in the knowledge discovery. They compile and build knowledge through a variety of experiences that allow the formation of knowledge. They have to undergo their own experiences, which in turn give the spark of thinking about specific knowledge. The most important thing in learning is that students need to master how to learn. Thus, they can become independent learners and find for themselves knowledge they need in life.

Cognitive structures are facts, concepts and generalizations that have been studied and remembered by the students. On the first level of learning, information can be communicated to students in the form of learning discovery that presents information in its final form, and the form of acceptance that learning requires students to find their own part or all of the material that will be taught. In the second level, students connect or associate the information into the knowledge they already owned, in this case meaningful learning happens. However, students can also just try to memorize new information, without connecting it to concepts that already exist in the cognitive structure; in this case, rote learning takes place.

\section{CONCLUSIONS}

Based on the results of the classroom action research, it can be summarized and concluded as follows: (1) The application of the teaching media using simple e-voting can increase the activities and students' learning outcomes on Civic Education subject. At the end of the first cycle and the second cycle, the formative tests were given to assess the improvement of students' learning outcomes through the implementation of the teaching medium using simple e-voting application.

Subsequently, it can be concluded that the implementation of the teaching medium using simple e-voting application can improve learning outcomes and learning activities. The implementation of the teaching medium using the simple evoting application can improve student learning outcomes through debriefing activities, discussions and group work.

In applying any teaching media, including the simple evoting application, teachers must have the knowledge and ability to utilize the media, so any confusions during the application of the media does not occur. Moreover, learning activities are very important since the activities can create student involvement which isinstrumental in achieving the learning objectives and affect the learning outcomes as well. To avoid any other difficulties encountered in the implementation of any teaching media, making clear rules and providing more learning facilities are necessary to create meaningful and interesting learning experience.

\section{REFERENCES}

[1] L. Wilardjo, Problematika Pendidikan, Jakarta : PT. Bintang Perkasa, 2010.

[2] F. Rusdayanto, Potret Buram Pendidikan Kita, Jakarta: PT. Pena Emas, 2010.

[3] W. Sanjaya, Strategi Pembelajaran Berorientasi Standar Proses Pendidikan, Jakarta: Kencana Prenada Media, 2011.

[4] W. Sanjaya, Perencanaan dan Desain Sistem Pembelajaran., Jakarta: Kencana, 2009.

[5] Sardiman, Interaksi Dan Motivasi Belajar Mengajar, Jakarta: PT. Raja Grafindo Persada, 2008. 